\title{
Alcohol dehydrogenase activity in Lactococcus chungangensis: Application in cream cheese to moderate alcohol uptake
}

\author{
Maytiya Konkit, Woo Jin Choi, and Wonyong Kim ${ }^{1}$ \\ Department of Microbiology, Chung-Ang University College of Medicine, Seoul 156-756, Republic of Korea
}

\begin{abstract}
Many human gastrointestinal facultative anaerobic and aerobic bacteria possess alcohol dehydrogenase $(\mathrm{ADH})$ activity and are therefore capable of oxidizing ethanol to acetaldehyde. However, the ADH activity of Lactococcus spp., except Lactococcus lactis ssp. lactis, has not been widely determined, though they play an important role as the starter for most cheesemaking technologies. Cheese is a functional food recognized as an aid to digestion. In the current study, the $\mathrm{ADH}$ activity of Lactococcus chungangensis CAU $28^{\mathrm{T}}$ and 11 reference strains from the genus Lactococcus was determined. Only 5 strains, 3 of dairy origin, L. lactis ssp. lactis KCTC $3769^{\mathrm{T}}$, L. lactis ssp. cremoris KCCM $40699^{\mathrm{T}}$, and Lactococcus raffinolactis DSM $20443^{\mathrm{T}}$, and 2 of nondairy origin, Lactococcus fujiensis $\mathrm{NJ}_{317^{\mathrm{T}}}$ and Lactococcus chungangensis CAU $28^{\mathrm{T}}$ KCTC $13185^{\mathrm{T}}$, showed $\mathrm{ADH}$ activity and possessed the $A D H$ gene. All these strains were capable of making cheese, but the highest level of ADH activity was found in L. chungangensis, with $45.9 \mathrm{nmol} / \mathrm{min}$ per gram in tryptic soy broth and $65.8 \mathrm{nmol} / \mathrm{min}$ per gram in cream cheese. The extent that consumption of cheese, following imbibing alcohol, reduced alcohol uptake was observed by following the level of alcohol in the serum of mice. The results show a potential novel benefit of cheese as a dairy functional food.
\end{abstract}

Key words: Lactococcus, Lactococcus chungangensis, cream cheese, alcohol dehydrogenase

\section{INTRODUCTION}

Lactic acid bacteria are widely used in many kinds of dairy products in many countries in the world. The lactic acid bacteria group comprises many bacterial species that play an important role in milk fermentation processes, including Lactococcus, Lactobacillus, Streptococcus thermophilus, and Leuconostoc mesen-

Received April 11, 2015.

Accepted May 25, 2015.

${ }^{1}$ Corresponding author: kimwy@cau.ac.kr teroides (Molimard and Spinnler, 1996; Bockelmann et al., 1997; Beresford et al., 2001; Bockelmann and Hoppe-Seyler, 2001). Members of the genus Lactococcus (Schleifer et al., 1985) are used extensively in the dairy and food fermentation industry, a multibillion-dollar biotech industry. Lactococcus lactis has been the major bacteria used in cheese manufacture for over 8,000 yr, with an excess of 1,000 varieties worldwide (Sandine and Elliker, 1970). Currently, the genus comprises 9 species and 4 subspecies with validly published names (Parte, 2014).

Several metabolic properties of Lactococcus serve special functions that directly or indirectly affect processes, such as flavor development and ripening of cheese (Olson, 1990) and the probiotic and prebiotic activity of cheese as a functional food. These functions include depletion of the milk sugar lactose, reduction of the redox potential of the cheese, citrate fermentation, and casein degradation to produce bioactive and antimicrobial peptides. These metabolic functions must be mediated by enzymes and many reports have been published on those that play important roles in cheese, especially from L. lactis (Engels et al., 2000; Yvon and Rijnen, 2001). Lactococcus lactis is studied predominantly for its role in fermented dairy products, including fermented milks, sour cream, and soft and hard cheese (Ward et al., 2002). Lactococcus lactis ssp. lactis and L. lactis ssp. cremoris are widely used as starters; for example, in Cheddar cheese production where they are favored because they are less likely to cause bitterness and other flavor defects (Heap, 1998).

Lactococcus, in particular, has a complex proteolytic system capable of converting milk casein to the free AA and peptides necessary for growth and acid production. The proteolytic system is composed of a proteinase involved in the initial cleavage of casein, peptidases that hydrolyze the large peptides formed, and transport systems for the uptake of small peptides and AA (Law and Haandrikman, 1997). Many enzymes that are important for degradation of casein and other proteins are present in L. lactis, such as endopeptidase (Muset et al., 1989), aminopeptidase (Thomas and Pritchard, 1987), dipeptidase (van Boven et al., 1988), tripeptidase (Bosman et al., 1990), and proline-specific peptidase (Baankreis 
and Exterkate, 1991). However, not only proteinases can be found in Lactococcus species but also other catabolic enzymes, such as alcohol dehydrogenase. Alcohol dehydrogenase (ADH) metabolizes a wide variety of substrates, including ethanol, retinol, aliphatic alcohols, hydroxysteroids, and lipid peroxidation products (Agarwal, 2001). Many studies have detailed the $A D H$ gene and its activity for Lactococcus lactis ssp. lactis in the field of sugar and ethanol production (Even et al., 2001; Palmfeldt et al., 2004; Gaspar et al., 2011; Solem et al., 2013; Costa et al., 2014; Gänzle, 2015).

In human health, the effects of ingested alcohol on different organs, including the brain, depend on the ethanol concentration achieved and the duration of exposure. The main site of ethanol metabolism is the liver, although some metabolism also occurs in other tissues and can cause local damage there. The main pathway of ethanol metabolism involves its conversion to acetaldehyde, a reaction that is mediated by ADH (Edenberg, 2007). Many bacteria and other microorganisms (e.g., yeast) throughout the digestive tract can metabolize alcohol. For example, microorganisms normally found in the mouth oxidize alcohol to acetaldehyde in saliva (Salaspuro and Salaspuro, 2004). Many studies have linked cheese consumption and health; for example, it has been shown that cheese contains compounds that reduce the risk of dental caries in children and has a positive effect on dental health (Harper et al., 1986; Krobicka et al., 1987; Papas et al., 1995). The activity of $\mathrm{ADH}$ contributed by lactococci in cheese, especially at the higher levels in L. chungangensis, may increase the metabolism of alcohol in the gut and decrease the exposure of internal organs to alcohol.

Lactococcus chungangensis CAU $28^{\mathrm{T}}$ was isolated from activated sludge and characterized by a polyphasic approach including phenotypic properties, cellular FA composition, and 16S rRNA gene sequence analyses (Cho et al., 2008; Konkit et al., 2014). Lactococcus chungangensis $\mathrm{CAU} 28^{\mathrm{T}}$ grow under aerobic or facultative anaerobic conditions, catalase and oxidase is negative, and it can produce acid from D-glucose, D-fructose, D-sucrose, D-mannose, and D-mannitol, cellobiose, and starch. Leucine aminopeptidase and $\beta$-galactosidase are also produced by this strain. Analysis of the transcriptome of L. chungangensis revealed higher levels of expression of several key enzymes favorable for cheesemaking, in line with the increased metabolic diversity found in lactococci of nondairy origin, including an elevated expression of $\mathrm{ADH}$ compared with conventional starter cultures (Cho et al., 2008; Konkit et al., 2014). The objective of the present study was to evaluate the potential ADH activity of $L$. chungangensis in cheese and in vivo. A comparison was made with other cultures; namely, L. lactis ssp. lactis, L. lactis ssp. cremo- ris, and Lactococcus raffinolactis, which are routinely used in the dairy industry.

\section{MATERIALS AND METHODS}

\section{Bacterial Strains}

Lactococcus chungangensis CAU $28^{\mathrm{T}}$ (KCTC $13185^{\mathrm{T}}$, JCM $17100^{\mathrm{T}}$, DSM $22330^{\mathrm{T}}$, CIP $\left.109874^{\mathrm{T}}\right)$, L. lactis ssp. lactis KCTC $3769^{\mathrm{T}}$, L. lactis ssp. cremoris $\mathrm{KCCM}$ $40699^{\mathrm{T}}$, L. raffinolactis DSM $20443^{\mathrm{T}}$, L. lactis ssp. hordiniae KCTC $3768^{\mathrm{T}}$, L. lactis ssp. tructae $\mathrm{L} 105^{\mathrm{T}}$ (DSM $21502^{\mathrm{T}}$ ), Lactococcus garvieae KCTC $3772^{\mathrm{T}}$, L. piscium HRIA $68^{\mathrm{T}}$ (DSM 6634 ${ }^{\mathrm{T}}$ ), Lactococcus plantarum DSM $20686^{\mathrm{T}}$, Lactococcus taiwanensis $0905 \mathrm{C} 15^{\mathrm{T}}$ (NBRC $\left.109049^{\mathrm{T}}\right)$, Lactococcus formosensis NBRC $109475^{\mathrm{T}}$, and Lactococcus fujiensis $516^{\mathrm{T}}$ (DSM $27937^{\mathrm{T}}$ ) were cultured in tryptic soy broth (Becton, Dickinson and Company, Sparks, MD) as a selective medium consisting of a soybean-CN digest and dextrose (Al-Zoreky and Sandine, 1991 ) at $30^{\circ} \mathrm{C}$ for $24 \mathrm{~h}$. Strains were obtained from the Korean Collection for Type Cultures (KCTC; Taejon, Korea), the Korean Culture Center of Microorganisms (KCCM; Seoul, Korea), the Deutsche Sammlung von Mikroorganismen und Zellkulturen (DSM; Braunschweig, Germany), and the National Biological Resource Center (NBRC; Tokyo, Japan).

\section{Probing ADH Gene in Lactococcus Species}

Genomic DNA was extracted using i-genomic BYF DNA Extraction mini kit (iNtRON Biotechnology, Seoul, South Korea). Primers for the $A D H$ genes were designed using Primer 3 software (http://frodo.wi.mit. edu/primer3/) based on the complete genome sequence of L. lactis ssp. lactis Il1403 (GenBank accession number NC_002662) and L. lactis ssp. cremoris UC509 (GenBank accession number CP_003157). The primer sequences were as follows: forward $=5^{\prime}$-GGTTTGTGACCCAGGTATGGT-3' , and reverse $=5^{\prime}$-GTTCCAAGCACCACCAACTT-3'. The PCR reaction was $5 \mathrm{U}$ of Taq DNA polymerase (Beams Biotechnology, Seongnam, South Korea), $2.0 \mu \mathrm{L}$ of $10 \times$ Taq buffer, 1 $\mu \mathrm{L}$ of dNTP mixture, $1 \mu \mathrm{L}$ each of forward and reverse primer, and $3 \mu \mathrm{L}$ of genomic DNA as a template in a total volume of $20 \mu \mathrm{L}$. Amplifications were performed in a TProfessional Thermocycler (Biometra GmbH, Göttingen, Germany) as follows: an initial $95^{\circ} \mathrm{C}$ for 5 min, 30 cycles of denaturation with $95^{\circ} \mathrm{C} 1 \mathrm{~min}$, annealing $55^{\circ} \mathrm{C} 1 \mathrm{~min}$, extension $72^{\circ} \mathrm{C} 1 \mathrm{~min}$, and a final extension at $72^{\circ} \mathrm{C} 10$ min. After PCR amplification, 3 $\mu \mathrm{L}$ of each PCR product was checked on $1.2 \%$ Seakem LE agarose gel (FMC Bioproducts, Rockland, ME) and visualized with a Gel DOC XR ${ }^{+}$Imaging system (Bio- 
Rad Laboratories, Hercules, CA). The PCR products were sequenced using a BigDye Terminator Cycle Sequencing kit and an automatic DNA sequencer (Model 3730; Applied Biosystems, Foster City, CA) and were aligned using the CLUSTAL_X 1.81 program (Thompson et al., 1997) against corresponding sequences from the National Center for Biotechnology Information GenBank database.

\section{Cream Cheese Making}

Pasteurized milk (Pasteur Milk Co. Ltd., Seoul, South Korea) was heated at $68^{\circ} \mathrm{C}$ for $30 \mathrm{~min}$, cooled down, and $5 \%$ (vol/vol) of a starter, L. chungangensis CAU28 ${ }^{\mathrm{T}}$, L. lactis ssp. lactis KCTC $3769^{\mathrm{T}}$, L. lactis ssp. cremoris KCCM $40699^{\mathrm{T}}$, L. raffinolactis DSM $20443^{\mathrm{T}}$, and L. fujiensis $516^{\mathrm{T}}$ was added and incubated at $30^{\circ} \mathrm{C}$ for $48 \mathrm{~h}$; in this period the milk was acidified. It was then stirred and heated at $70^{\circ} \mathrm{C}$ for 5 min and the whey was separated through a cloth bag. The curd was set and the whey drained by adding $0.5 \%$ salt. Finally, each cream cheese sample was freeze dried and stored in the dark at $4^{\circ} \mathrm{C}$ until further tests.

\section{Measuring Cell Viability and Cytotoxicity}

Murine macrophages of the RAW 264.7 cell line were obtained from the Korean Cell Line Bank (Seoul, South Korea). The RAW 264.7 cells were grown in Dulbecco's minimum essential medium (Lonza, Walkersville, MD) containing 10\% heat-inactivated fetal bovine serum (Gibco BRL, Grand Island, NY) and $20 \mu \mathrm{g} / \mathrm{mL}$ of gentamycin (Gibco) at $37^{\circ} \mathrm{C}$ in a water-jacketed $5 \%$ $\mathrm{CO}_{2}$ incubator (model 3111, Thermo Fisher Scientific, Waltham, MA). Cellular density and viability were determined by standard microscopic observations, using a hemocytometer after trypan blue staining.

\section{Cell Viability Assay}

Cell viability was determined using $10 \mathrm{mg} / \mathrm{mL}$ of each cream cheese sample in triplicate with RAW 264.7 cells $\left(5 \times 10^{5}\right.$ cells/well $)$ seeded in 24 -well plates. After $24 \mathrm{~h}$ of treatment, the cells were subjected to 3-(4,5-dimethylthiazol-2-yl-2,5-diphenyltetrazolium bromide) (MTT) assay. Medium was replaced by 500 $\mu \mathrm{L}$ of fresh serum-free medium containing $0.5 \mathrm{mg} / \mathrm{mL}$ of MTT (Sigma-Aldrich, St. Louis, MO). After incubation for $1 \mathrm{~h}$ at $37^{\circ} \mathrm{C}$ in $5 \% \mathrm{CO}_{2}$, MTT-containing medium was removed, and the reduced formazan dye was solubilized by adding $500 \mu \mathrm{L}$ of dimethyl sulfoxide (Sigma-Aldrich) to each well. After gentle mixing, the absorbance was monitored at $590 \mathrm{~nm}$.

\section{Lactate Dehydrogenase Release Assay}

Cell cytotoxicity was evaluated using $10 \mathrm{mg} / \mathrm{mL}$ each of cream cheese samples in triplicate with RAW 264.7 cells plated at a density of $2 \times 10^{4}$ cells in 96-well cell culture plates with $100 \mu \mathrm{L}$ of culture medium and incubated for $24 \mathrm{~h}$. Cells were evaluated by measuring the release of the enzyme lactate dehydrogenase (LDH) using an LDH cytotoxicity detection kit (Takara Bio Inc., Shiga, Japan). A value for maximal LDH release was obtained from the supernatant of cells treated with $1 \%$ Triton X-100 (Sigma-Aldrich). The percentage of LDH release was calculated using the following equation:

$$
\begin{aligned}
& 100 \times(\text { experimental LDH release } \\
& - \text { spontaneous LDH release }) /(\text { maximal LDH release } \\
& - \text { spontaneous LDH release })
\end{aligned}
$$

\section{In Vitro Assay of ADH Activity}

Alcohol dehydrogenase activity was determined enzymatically by a modification of the method by Lebsack and Anderson (1979) and Bostian and Betts (1978). The reaction mixture contained 1.0 $M$ Tris/HCl buffer (pH 8.8), $20 \mathrm{mM} \mathrm{NAD}{ }^{+}$, and $0.2 M$ ethanol in a final volume of $3.0 \mathrm{~mL}$. The ADH activity from Saccharomyces cerevisiae (Sigma-Aldrich) was used for calibration. To determine the ADH activity of bacteria, $1 \mathrm{~mL}$ of 1 $\times 10^{6}$ cells of each Lactococcus strain, in triplicate, was added to the reaction mixture and incubated at $30^{\circ} \mathrm{C}$ for $5 \mathrm{~min}$. The absorbance was measured at $340 \mathrm{~nm}$ and compared with a standard curve to determine ADH. For cream cheese samples, $10 \mathrm{mg} / \mathrm{mL}$ of each cream cheese sample was added and the reaction mixture was incubated at $30^{\circ} \mathrm{C}$ for $5 \mathrm{~min}$. The absorbance was measured at $340 \mathrm{~nm}$ and compared with a standard curve.

\section{In Vivo Assay of ADH Activity}

Animal Administrations. As the levels of ADH activity in cream cheese were higher than in cell cultures they were used to determine the effect of $L$. chungangensis $\mathrm{CAU} 28^{\mathrm{T}}$ on alcohol levels in the mouse model. Seven-week-old male Imprinting Control Region (ICR) mice were purchased from Samtako (Samtako, Osan, South Korea). They were acclimatized for $1 \mathrm{wk}$ before the experiment and were housed in cages in a room maintained at $22^{\circ} \mathrm{C}$ under a 12 -h day/night cycle throughout the experiment. The mice were divided into 7 groups ( $\mathrm{n}=5$ for each group), as follows: (1) normal (untreated) group; (2) control (ethanol) group; (3) cream cheese made from L. chungangensis (100 $\mathrm{mg} / \mathrm{kg}$ )-treated group; (4) cream cheese made from $L$. 
fujiensis (100 mg/kg)-treated group; (5) cream cheese made from L. lactis ssp. cremoris $(100 \mathrm{mg} / \mathrm{kg})$-treated group; (6) cream cheese made from L. lactis ssp. lactis $(100 \mathrm{mg} / \mathrm{kg}$ )-treated group; and (7) cream cheese made from L. raffinolactis (100 mg/kg)-treated group. Before the test, mice were starved for $18 \mathrm{~h}$. Ethanol and sample were administered orally. Mice were administered with $22 \%$ ethanol ( $2 \mathrm{~g}$ of ethanol $/ \mathrm{kg}$ of BW).

Determination of Blood Alcohol Concentration in Mouse Blood. After the alcohol challenge, whole-blood samples were taken at $1,3,5$, and $7 \mathrm{~h}$ from the tail veins of the experimental ICR mice into a serum separation tube. Then, the blood samples were centrifuged at $241.48 \times g$ for $15 \mathrm{~min}$ at $4^{\circ} \mathrm{C}$ and incubated at $4^{\circ} \mathrm{C}$ for $10 \mathrm{~min}$. The supernatant, consisting of blood serum, was used in the analysis of the serum alcohol concentration level of alcohol. The reaction mixture contained $0.3 \mathrm{M} \mathrm{KH}_{2} \mathrm{PO}_{4}$ buffer (pH 9.0), 49 $\mathrm{m} M \mathrm{NAD}^{+}$, and serum sample to a final volume of 3.0 $\mathrm{mL}$. The reaction mixture was incubated at $20^{\circ} \mathrm{C}$ for $5 \mathrm{~min}$. The absorbance was measured at $340 \mathrm{~nm}$ in a spectrophotometer (A1). After measurement, $50 \mu \mathrm{L}$ of $\mathrm{ADH}$ was added and incubated at $20^{\circ} \mathrm{C}$ for $5 \mathrm{~min}$. The absorbance was measured at $340 \mathrm{~nm}$ in a spectrophotometer (A2). The alcohol concentration was calculated using the following equation:

$$
\text { Concentration }=0.7259 / 3.6 \times \Delta \mathrm{A},
$$

where $\Delta \mathrm{A}=$ sample $(\mathrm{A} 2-\mathrm{A} 1)-$ blank $(\mathrm{A} 2-\mathrm{A} 1)$.

\section{Statistical Analysis}

All measurements were expressed as the mean \pm standard deviation and performed in triplicate. Statis- tical analyses of the differences between samples were carried out by a one-way ANOVA, followed by post hoc multiple comparisons using the Duncan and $t$-tests in the predictive analytics software statistics package for Windows (Microsoft Corp., Redmond, WA). Differences of $P<0.01$ were considered statistically significant.

\section{RESULTS}

\section{Detection of ADH Gene}

Alcohol dehydrogenase genes code for a ubiquitous group of enzymes that catalyze the interconversion between alcoholic compounds and their corresponding aldehydes or ketones in living microorganisms. A PCR with $A D H$ primers with all 9 species and 4 subspecies of Lactococcus found that only 5 strains - L. chungangensis CAU $28^{\mathrm{T}}$, L. fujiensis $516^{\mathrm{T}}$, L. lactis ssp. cremoris, L. lactis ssp. lactis, and L. raffinolactis - have the $A D H$ gene, indicated by a strong band from PCR with $A D H$ specific primers (748 bp in size; Figure 1). Sequence analysis of the $A D H$ gene revealed that $L$. chungangensis CAU $28^{\mathrm{T}}$ exhibited $98 \%$ sequence identity to the $L$. raffinolactis 4877 ADH gene.

\section{Cream Cheese Making}

Cream cheese was made using each of 5 strains of Lactococcus, L. chungangensis CAU $28^{\mathrm{T}}$, L. fujiensis $516^{\mathrm{T}}$, L. lactis ssp. cremoris, L. lactis ssp. lactis, and L. raffinolactis, individually as starter culture. All 5 cheese products had a white uniform, soft, and smooth texture, with no odor, and did not show any indication of cracking or whey loss. They were spreadable at room temperature or when cold and had medium firmness

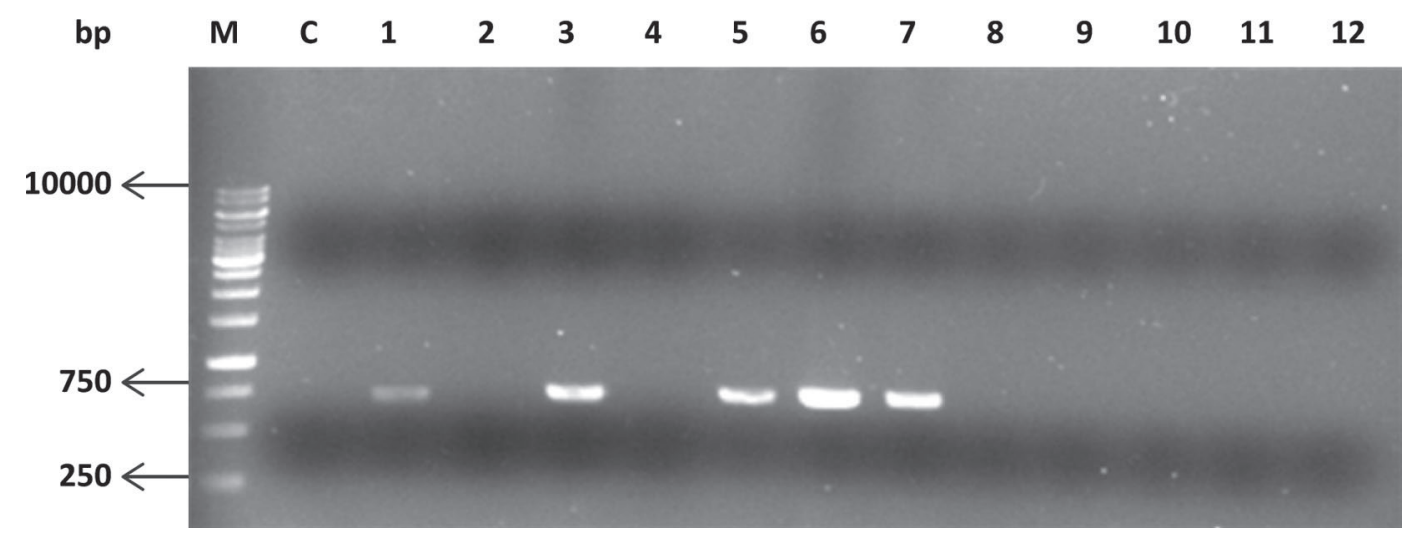

Figure 1. Gel electrophoresis from PCR product of $A D H$ gene in all Lactococcus spp. $\mathrm{M}=$ marker; $\mathrm{C}=$ negative control; $1=$ Lactococcus

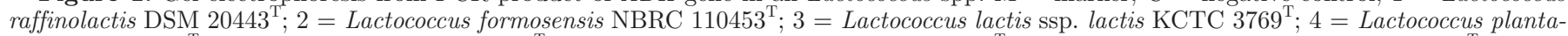
rum DSM $20686^{\mathrm{T}} ; 5=$ Lactococcus fujiensis $516^{\mathrm{T}} ; 6=$ Lactococcus chungangensis CAU $28^{\mathrm{T}} ; 7=$ L. lactis ssp. cremoris KCCM $40699^{\mathrm{T}} ; 8=$ L. lactis ssp. hordiniae $\mathrm{KCTC} 3768^{\mathrm{T}} ; 9=$ L. lactis ssp. tructae $\mathrm{L} 105^{\mathrm{T}} ; 10=$ Lactococcus taiwanensis $0905 \mathrm{C} 15^{\mathrm{T}} ; 11=$ Lactococcus garvieae $\mathrm{KCTC}$ $3772^{\mathrm{T}} ; 12=$ Lactococcus piscium HRIA $68^{\mathrm{T}}$. 
when refrigerated. The $\mathrm{pH}$ values of all cream cheeses were in the range of 4.4 to 4.9 and the moisture content was between 55 and $60 \%$.

\section{Cell Viability and Cytotoxicity of Cream Cheese Samples}

The cytotoxic effects of each cream cheese sample were evaluated with RAW 264.7 cells by using the MTT assay and LDH assay. No cytotoxic effects at a concentration of $10 \mathrm{mg} / \mathrm{mL}$ of each cream cheese sample were observed after incubation for $24 \mathrm{~h}$ with RAW 264.7 cells using the MTT assay (Figure 2A). RAW 264.7 cells treated with cream cheese from $L$. chungangensis CAU $28^{\mathrm{T}}$ had cell viabilities higher than the control and the 4 other Lactococcus spp. $(P=0.01)$. In addition, RAW 264.7 cells incubated with cream cheese released $\mathrm{LDH}$ at a barely detectable level from all strains, $L$. chungangensis $\mathrm{CAU} 28^{\mathrm{T}}$ showed the lowest values of LDH released $(P=0.01)$. All the cheese samples from the 5 strains of Lactococcus species had a low cytotoxicity using $\mathrm{LDH}$ as a biomarker (Figure 2B).

\section{In Vitro ADH Activity}

The metabolic activity of ADH in cells grown in tryptic soy broth was determined by measuring the generation of reduced NADH by ADH. In total out of the 12 strains of Lactococcus species, only 5 strains, including L. chungangensis CAU $28^{\mathrm{T}}$, L. lactis ssp. cremoris, L. lactis ssp. lactis, L. fujiensis $516^{\mathrm{T}}$, and L. raffinolactis, have the $A D H$ gene and showed $\mathrm{ADH}$ activity. The level of $\mathrm{ADH}$ activity in $L$. chungangensis $\mathrm{CAU} 28^{\mathrm{T}}$ was higher than other Lactococcus strains at $45.9 \mathrm{nmol} /$ min per gram, whereas L. lactis ssp. cremoris, L. lactis ssp. lactis, L. fujiensis $516^{\mathrm{T}}$, and L. raffinolactis have ADH activities of $40.8,37.9,33.4$, and $30.2 \mathrm{nmol} / \mathrm{min}$ per gram, respectively (Figure 3A). The activity of $\mathrm{ADH}$ in cream cheese made from Lactococcus strains was determined by measuring the generation of reduced $\mathrm{NADH}$ by $A D H$. The ADH activity of cream cheese from L. chungangensis CAU $28^{\mathrm{T}}$ was higher than other Lactococcus strains at $69.6 \mathrm{nmol} / \mathrm{min}$ per gram. The $\mathrm{ADH}$ activity in cream cheese made from L. lactis ssp. cremoris, L. lactis ssp. lactis, L. fujiensis $516^{\mathrm{T}}$, and L. raffinolactis was $65.8,65.7,56.5$, and $43.9 \mathrm{nmol} / \mathrm{min}$ per gram, respectively (Figure 3B).

\section{In Vivo ADH Activity}

Because ADH activities in bacterial cells were lower than those in cream cheese, cream cheese was chosen to determine the effect of ADH from L. chungangensis
CAU $28^{\mathrm{T}}$ on blood alcohol levels in the mouse. In vivo, the studies measured the alcohol concentrations in mouse serum after ingestion of ethanol with and without cream cheese. Overall, the results obtained from the animal treatment correlated with the in vitro study. After $3 \mathrm{~h}$, blood alcohol concentrations peaked (Figure 4). After $5 \mathrm{~h}$, significant differences in the concentration of alcohol were observed. The alcohol concentration in the blood of mice that ate cheese using $L$. chungangensis CAU $28^{\mathrm{T}}$ as a starter culture was lower than that for any other Lactococcus strains at $429.7 \mathrm{nmol} / \mathrm{mL}$. The alcohol concentrations in the blood of L. lactis ssp. cremoris, L. fujiensis $516^{\mathrm{T}}$, L. raffinolactis, and L. lactis ssp. lactis were $550.1,565.4,577.6$, and $615.5 \mathrm{nmol} /$ $\mathrm{mL}$, respectively, compared with $774.6 \mathrm{nmol} / \mathrm{mL}$ in the control.

\section{DISCUSSION}

The role of starter organisms in cheese manufacture is related to the activity of many enzymes involved in the conversion of AA and their regulation, key aspects of flavor formation during cheese ripening (MartínezCuesta et al., 2013). Lactococcus species are important organisms used as starters in cheese manufacture, performing acidification through the production of organic acids, mainly lactic acid (Leroy and De Vuyst, 2004); but a fraction of the intermediate pyruvate can alternatively be converted to various flavor compounds. Lactococcus lactis is characterized by having different enzymatic activities that act during cheese production and affect the organoleptic properties in terms of texture, flavor, and aroma development (Kunji et al., 1996; Smit et al., 2005). The typical flavor of each cheese variety is determined by the presence of volatile compounds and their relative concentration (Collins et al., 2003; Smit et al., 2005).

The proteolytic system of lactic acid bacteria is essential for their growth in milk and contributes significantly to flavor development in fermented milk products, where these microorganisms are used as starter cultures. The proteolytic system is composed of proteinases, which initially cleave the milk protein to peptides, peptidases, which cleave the peptides thus formed into smaller peptides, and AA and transport systems, which are involved in the cellular uptake of small peptides and AA (Law and Haandrikman, 1997).

A beneficial association of microorganisms with the human host was probably first suggested by Döderlein (1892), who proposed that vaginal bacteria produced lactic acid from sugars to prevent or inhibit the growth of pathogenic bacteria. Lactococcus was also found in association with fermented milk products, which were 

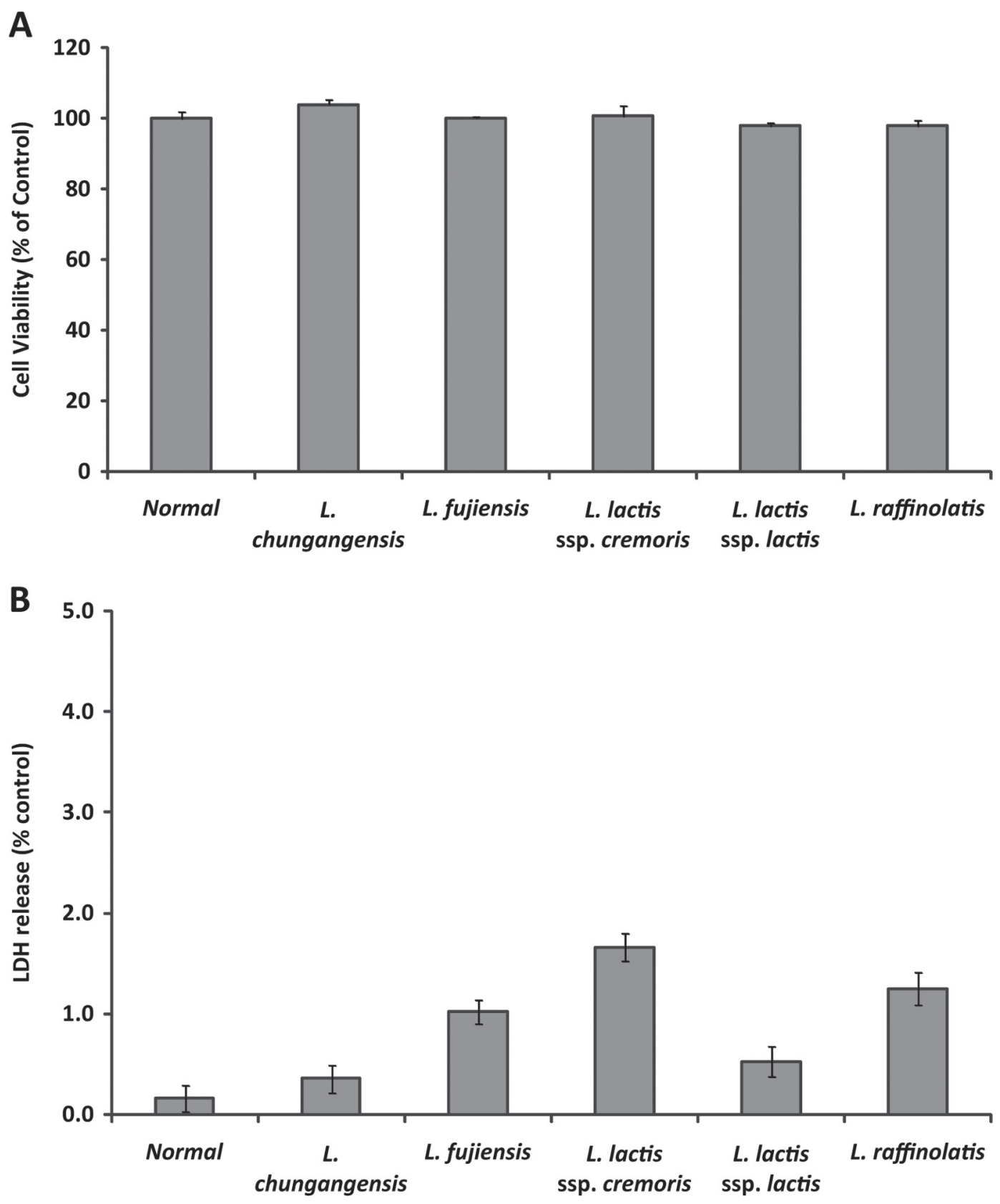

Figure 2. The cell cytotoxicity of RAW 264.7 cells treated with 5 cream cheese samples $(10 \mathrm{mg} / \mathrm{mL})$. The normal group was treated with medium only. Results are expressed as mean \pm SD from 5 independent experiments. (A) Cell viability treated with cream cheese from 5 strains of Lactococcus; (B) lactate dehydrogenase (LDH) released from cream cheese of 5 strains of Lactococcus.

advocated for their health benefits (Metchnikoff, 1908). The technically important Lactococcus spp., which are generally considered to be nonpathogenic and generally safe in relation to food and probiotics, can also be used to improve the health of humans and animals (Holzapfel et al., 2001).

Alcohol dehydrogenase is an enzyme abundant in all domains of life, primer design for $\mathrm{ADH}$ used sequence data from all species and found the $A D H$ gene in only
5 strains-L. fujiensis $516^{\mathrm{T}}$, L. lactis ssp. cremoris, L. lactis ssp. lactis, and L. raffinolactis, and L. chungangensis CAU $28^{\mathrm{T}}$ - with L. chungangensis showing the highest activity. Cream cheese is very versatile food product, appealing to many palates and suitable for all age groups, and provides a valuable alternative to fermented milks and yogurts as a food vehicle for probiotic delivery (da Cruz et al., 2009). The 5 strains possessing the $A D H$ gene were chosen for the study for 



Figure 3. (A) Alcohol dehydrogenase (ADH) activity from cell of 5 Lactococcus species; (B) ADH activity in cheese from 5 Lactococcus species.

the effect of cream cheese on moderating blood alcohol levels in the mouse model. The strains without an $A D H$ gene were not successful at making cream cheese, so an $A D H$ negative control was not available.

In the human body, the effects of alcohol (i.e., ethanol) on various tissues depend on its concentration in the blood. Alcohol metabolism is achieved by both oxidative pathways, which either add oxygen or remove hydrogen, and involves ADH. Alcohol dehydrogenase is the major enzyme responsible for the oxidation of ethanol. Ethanol is oxidized to acetaldehyde through the action of this enzyme (Seitz and Becker, 2007), which is present largely in the liver and consists of a family of isoforms. 


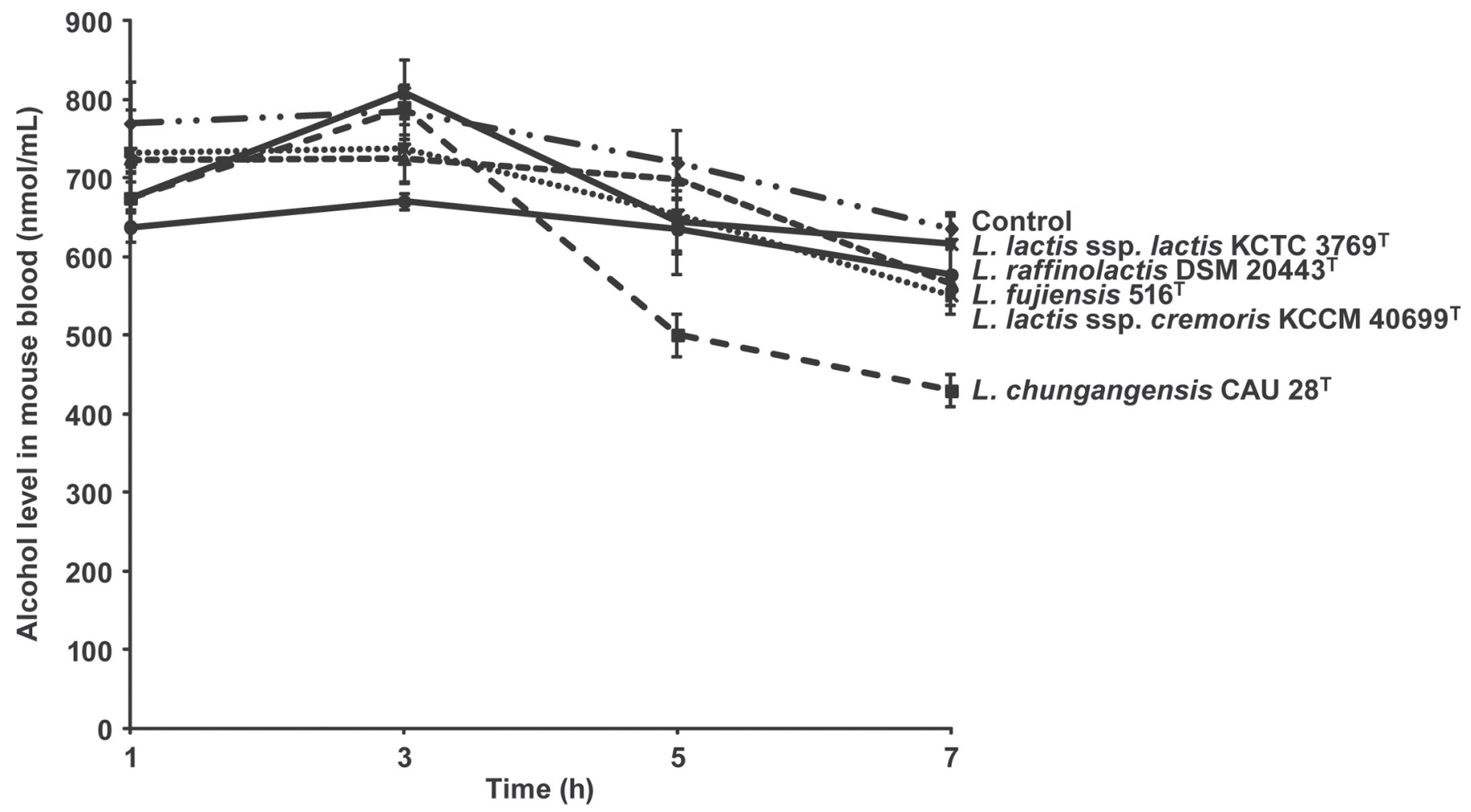

Figure 4. Effects of cream cheese on alcohol concentrations in mouse blood. Mice were orally administered $22 \%$ ethanol $(2 \mathrm{~g} / \mathrm{kg}$ of BW). Blood alcohol and acetaldehyde concentration were measured at 1,3,5, and $7 \mathrm{~h}$ after ethanol administration. The results are expressed as the mean \pm SD from 5 independent experiments.

The ADH reaction is reversible, as bacteria and yeast throughout the digestive tract can metabolize alcohol by this reaction (Cederbaum, 2012). For example, bacteria normally found in the mouth oxidize alcohol to acetaldehyde in the saliva. The 5 lactococcal strains that have the capacity to make cream cheese also show high levels of ADH. With this high amount, our results show that this enzyme can reduce the level of alcohol in mouse blood that results from ingestion of ethanol. In particular, a correlation was observed between the amount of $\mathrm{ADH}$ and the decrease in blood alcohol. Cream cheese made from L. chungangensis CAU $28^{\mathrm{T}}$, which had the highest ADH activity, decreased the peak alcohol concentration to $54.5 \%$ compared with the control.

Our results show that all 5 strains of Lactococcus have ADH activity in cell culture and cheese, with the highest level expressed in L. chungangensis; however, the amount of $\mathrm{ADH}$ activity in cell culture is lower than in cheese, implying that ADH activity is induced in the cheese environment. In conclusion, L. chungangensis CAU $28^{\mathrm{T}}$ has a high level of $\mathrm{ADH}$, and as a cheese starter may provide a health benefit by metabolizing alcohol in the gut rather than in organs such as the liver.

\section{REFERENCES}

Agarwal, D. P. 2001. Genetic polymorphisms of alcohol metabolizing enzymes. Pathol. Biol. (Paris) 49:703-709.

Al-Zoreky, N., and W. Sandine. 1991. Lactococcus genus: A selective and differential agar medium. J. Food Sci. 56:1729-1730.

Baankreis, R., and F. A. Exterkate. 1991. Characterisation of a peptidase from Lactococcus lactis ssp. Lactococcus cremoris HP that hydrolyses di-and tripeptides containing proline or hydrophobic residues as the aminoterminal amino acid. Syst. Appl. Microbiol. 14:317-323.

Beresford, T. P., N. A. Fitzsimons, N. L. Brennan, and T. M. Cogan. 2001. Recent advances in cheese microbiology. Int. Dairy J. $11: 259-274$.

Bockelmann, W., and T. Hoppe-Seyler. 2001. The surface flora of bacterial smear-ripened cheeses from cow's and goat's milk. Int. Dairy J. 11:307-314.

Bockelmann, W., U. Krusch, G. Engel, N. Klijn, G. Smit, and K. Heller. 1997. The microflora of Tilsit cheese. Part 1. Variability of the smear flora. Nahrung 41:208-212. http://dx.doi.org/10.1002/ food.19970410405.

Bosman, B. W., P. S. Tan, and W. N. Konings. 1990. Purification and characterization of a tripeptidase from Lactococcus lactis ssp. cremoris Wg2. Appl. Environ. Microbiol. 56:1839-1843.

Bostian, K. A., and G. F. Betts. 1978. Rapid purification and properties of potassium-activated aldehyde dehydrogenase from Saccharomyces cerevisiae. Biochem. J. 173:773-786.

Cederbaum, A. I. 2012. Alcohol metabolism. Clin. Liver Dis. 16:667685.

Cho, S. L., S. W. Nam, J. H. Yoon, J. S. Lee, A. Sukhoom, and W. Kim. 2008. Lactococcus chungangensis sp. nov., a lactic acid bacterium isolated from activated sludge foam. Int. J. Syst. Evol. Microbiol. 58:1844-1849. 
Collins, Y. F., P. L. McSweeney, and M. G. Wilkinson. 2003. Lipolysis and free fatty acid catabolism in cheese: A review of current knowledge. Int. Dairy J. 13:841-866.

Costa, R. S., A. Hartmann, P. Gaspar, A. R. Neves, and S. Vinga. 2014. An extended dynamic model of Lactococcus lactis metabolism for mannitol and 2, 3-butanediol production. Mol. Biosyst. 10:628-639.

da Cruz, A. G., F. C. A. Buriti, C. H. B. de Souza, J. A. F. Faria, and S. M. I. Saad. 2009. Probiotic cheese: Health benefits, technological and stability aspects. Trends Food Sci. Technol. 20:344-354.

Döderlein, A. 1892. The vaginal transsudate and its significance for childbed fever. Centralblatt für Bacteriologie 11:699-700.

Edenberg, H. I. 2007. The genetics of alcohol metabolism: Role of alcohol dehydrogenase and aldehyde dehydrogenase variants. Alcohol Res. Health. 30:5-13.

Engels, W. J., A. C. Alting, M. M. Arntz, H. Gruppen, A. G. Voragen, G. Smit, and S. Visser. 2000. Partial purification and characterization of two aminotransferases from Lactococcus lactis ssp.cremoris B78 involved in the catabolism of methionine and branched-chain amino acids. Int. Dairy J. 10:443-452.

Even, S., N. D. Lindley, and M. Cocaign-Bousquet. 2001. Molecular physiology of sugar catabolism in Lactococcus lactis IL1403. J. Bacteriol. 183:3817-3824.

Gänzle, M. G. 2015. Lactic metabolism revisited: Metabolism of lactic acid bacteria in food fermentations and food spoilage. Curr. Opin. Food Sci. 2:106-117.

Gaspar, P., A. R. Neves, M. J. Gasson, C. A. Shearman, and H. Santos. 2011. High yields of 2, 3-butanediol and mannitol in Lactococcus lactis through engineering of NAD+ cofactor recycling. Appl. Environ. Microbiol. 77:6826-6835.

Harper, D. S., J. Osborn, J. Hefferren, and R. Clayton. 1986. Cariostatic evaluation of cheeses with diverse physical and compositional characteristics. Caries Res. 20:123-130.

Heap, H. 1998. Optimising starter culture performance in NZ cheese plants. Aust. J. Dairy Technol. 53:74-78.

Holzapfel, W. H., P. Haberer, R. Geisen, J. Björkroth, and U. Schillinger. 2001. Taxonomy and important features of probiotic microorganisms in food and nutrition. Am. J. Clin. Nutr. 73:365S$373 \mathrm{~S}$.

Konkit, M., J. H. Kim, N. Bora, and W. Kim. 2014. Transcriptomic analysis of Lactococcus chungangensis sp. nov. and its potential in cheese making. J. Dairy Sci. 97:7363-7372.

Krobicka, A., W. Bowen, S. Pearson, and D. Young. 1987. The effects of cheese snacks on caries in desalivated rats. J. Dent. Res. 66:1116-1119.

Kunji, E. R., I. Mierau, A. Hagting, B. Poolman, and W. N. Konings. 1996. The proteotytic systems of lactic acid bacteria. Antonie Van Leeuwenhoek 70:187-221.

Law, J., and A. Haandrikman. 1997. Proteolytic enzymes of lactic acid bacteria. Int. Dairy J. 7:1-11.

Lebsack, M. E., and A. Anderson. 1979. Further characterization of the inhibition of aldehyde dehydrogenase activity by pargyline. Res. Commun. Chem. Pathol. Pharmacol. 26:263-275.

Leroy, F., and L. De Vuyst. 2004. Lactic acid bacteria as functional starter cultures for the food fermentation industry. Trends Food Sci. Technol. 15:67-78.
Martínez-Cuesta, M. C., C. Peláez, and T. Requena. 2013. Methionine metabolism: Major pathways and enzymes involved and strategies for control and diversification of volatile sulfur compounds in cheese. Crit. Rev. Food Sci. Nutr. 53:366-385.

Metchnikoff, E. 1908. The Prolongation of Life: Optimistic Studies. G. P. Putnam's Sons, New York, NY.

Molimard, P., and H. Spinnler. 1996. Review: Compounds involved in the flavor of surface mold-ripened cheeses: Origins and properties. J. Dairy Sci. 79:169-184.

Muset, G., V. Monnet, and J.-C. Gripon. 1989. Intracellular proteinase of Lactococcus lactis ssp. lactis NCDO 763. J. Dairy Res. $56: 765-778$

Olson, N. F. 1990. The impact of lactic acid bacteria on cheese flavor. FEMS Microbiol. Lett. 87:131-147.

Palmfeldt, J., M. Paese, B. Hahn-Hägerdal, and E. W. Van Niel. 2004 The pool of ADP and ATP regulates anaerobic product formation in resting cells of Lactococcus lactis. Appl. Environ. Microbiol 70:5477-5484.

Papas, A. S., A. Joshi, A. J. Belanger, R. Kent, C. A. Palmer, and P. F. DePaola. 1995. Dietary models for root caries. Am. J. Clin. Nutr. 61:417S-422S

Parte, A. C. 2014. LPSN-List of prokaryotic names with standing in nomenclature. Nucleic Acids Res. 42:D613-D616.

Salaspuro, V., and M. Salaspuro. 2004. Synergistic effect of alcohol drinking and smoking on in vivo acetaldehyde concentration in saliva. Int. J. Cancer 111:480-483.

Sandine, W. E., and P. R. Elliker. 1970. Microbially induced flavor and fermented foods. Flavor in fermented dairy products. J. Agric. Food Chem. 18:557-562.

Schleifer, K. H., J. Kraus, C. Dvorak, R. Kilpperbalz, M. D. Collins, and W. Fischer. 1985. Transfer of Streptococcus-lactis and related streptococci to the genus Lactococcus gen. nov. Syst. Appl. Microbiol. 6:183-195.

Seitz, H. K., and P. Becker. 2007. Alcohol metabolism and cancer risk. Alcohol Res. Health 30:38-41.

Smit, G., B. A. Smit, and W. J. Engels. 2005. Flavour formation by lactic acid bacteria and biochemical flavour profiling of cheese products. FEMS Microbiol. Rev. 29:591-610.

Solem, C., T. Dehli, and P. R. Jensen. 2013. Rewiring Lactococcus lactis for ethanol production. Appl. Environ. Microbiol. 79:25122518

Thomas, T. D., and G. G. Pritchard. 1987. Proteolytic enzymes of dairy starter cultures. FEMS Microbiol. Lett. 46:245-268.

Thompson, J. D., T. J. Gibson, F. Plewniak, F. Jeanmougin, and D. G. Higgins. 1997. The CLUSTAL_X Windows interface: Flexible strategies for multiple sequence alignment aided by quality analysis tools. Nucleic Acids Res. 25:4876-4882.

van Boven, A., P. Tan, and W. Konings. 1988. Purification and characterization of a dipeptidase from Streptococcus cremoris Wg2. Appl. Environ. Microbiol. 54:43-49.

Ward, L. J. H., G. P. Davey, H. A. Heap, and W. J. Kelly. 2002. Lactococcus lactis. Pages 1511-1516 in Encyclopedia of Dairy Science. H. Roginski, J. Fuquay, and P. F. Fox, ed. Elsevier Science Ltd. London, UK.

Yvon, M., and L. Rijnen. 2001. Cheese flavour formation by amino acid catabolism. Int. Dairy J. 11:185-201. 